\title{
Pengaruh Suku Bunga, Nilai Tukar, Pertumbuhan Ekonomi, Kinerja Keuangan, Keputusan Pendanaan, Dan Keputusan Investasi Terhadap Nilai Perusahaan
}

\author{
Dwi Nova Wijaya ${ }^{\mathrm{a}}$, Mustaruddin ${ }^{\mathrm{b}}$, Giriati $^{\mathrm{b}}$

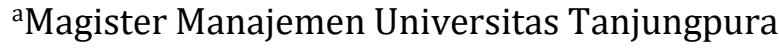 \\ bFakultas Ekonomi \& Bisnis Universitas Tanjungpura \\ Pontianak \\ Email : dwinovawijaya06@student.untan.ac.id
}

(Diterima Agustus 2020; Disetujui November 2020; Dipublikasikan Januari 2021)

\begin{abstract}
Value of the firm illustrates how well or not management manages its wealth. The firm's high value can increase prosperity for shareholders, so it can influence investor perception of the company. Every company is required to be able to process the important functions that exist in the company effectively and efficiently so that the company can be superior. Value of the firm can be influenced by macro-economic conditions in a country and micro-economics in industrial sectors. This study aims to test macro-economicfactors, namely, the influence of interest rates, exchange rates, economic growth and micro-economics, namely financial performance, funding decisions and investment decisions on the value of the firm. The population of this research is 100 companies at Kompas 100 listed on the Indonesia Stock Exchange in 2015 - 2019. Samples of this study as many as 51 companies were selected based on purposive sampling techniques. The data analysis method used is multiple linear regression analysis. The results showed that there is a negative and insignificant influence of interest rates, economic growth on the value of the firm. Exchange rates and investment decisions have a positive and insignificant effect on the value of the firm. Financial performance has a positive and significant effect on the value of the firm. Financial decisions have a negative and significant effect on the value of the company.
\end{abstract}

Keywords : Value of the Firm, Interest Rate, Exchange Rate, Economic Growth, Financial Performance, Financial Decisions and Investment Decisions

\section{PENDAHULUAN}

Nilai perusahaan merupakan persepsi investor terhadap suatu perusahaan, yang sering dihubungkan dengan harga saham. Harga saham yang tinggi menunjukkan nilai perusahaan tinggi danjika harga saham rendah menunjukkan nilai perusahaan yang rendah. Menurut Husnan (2000), nilai perusahaan merupakan harga yang bersedia dibayar oleh calon pembeli apabila perusahaan tersebut dijual. Dengan kata lain nilai perusahaan yang dibentuk melalui indikator nilai pasar saham, sangat 
dipengaruhi dari peluang investasi, dimana peluang investasi memberikan sinyal tentang pertumbuhan perusahaan dimasa mendatang, sehingga meningkatkan hargasaham sebagai indikator nilai perusahaan (signaling theory).

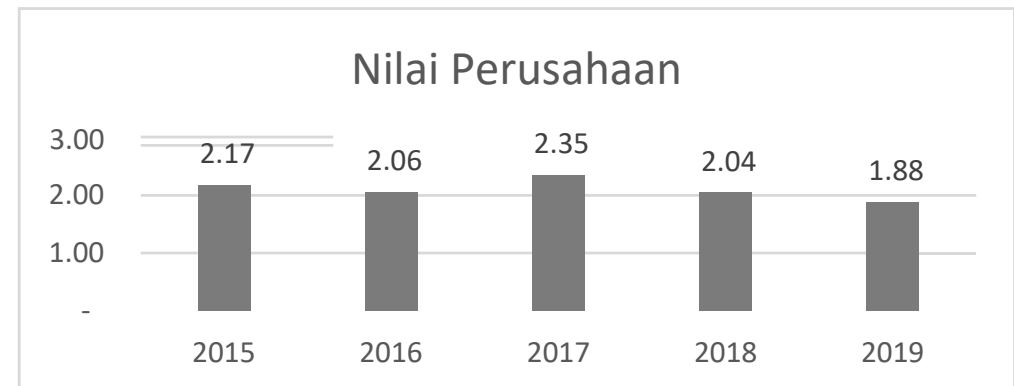

\section{Gambar 1. Rata-Rata Nilai Perusahaan Dalam Indeks Kompas 100 Periode} 2015- 2019

Sumber : IDX 2015-2019 yang diolah kembali

Nilai perusahaan pada grafik 1. diukur dengan price book value (PBV) yaitudihitung dengan membandingkan harga perlembar saham dengan nilai buku perlembar saham pada perusahaan yang tergabung dalam indeks Kompas 100 dari tahun 2015-2019. Berdasarkan Grafik 1. menunjukan nilai perusahaan yang naik turun dari tahun 2015 sampai dengan tahun 2019. Nilai perusahaan turun pada tahun 2016 yaiut 2,06 dari 2,17 pada tahun 2015, kemudian naik lagi ditahun 2017 menjadi 2,35 dan terus turun sampai dengan tahun 2019 yaitu 1,88. Nilai perusahaan dapat menggambarkan keadaan perusahaan. Baiknya nilai perusahaan, maka perusahaan akan dipandang baik oleh para calon investor. Nilai perusahaan dapat dipengaruhioleh kondisi makro ekonomi disuatu negara dan mikro ekonomi dalam sektor-sektor industri.

Faktor-faktor makro ekonomi diantaranya tingkat suku bunga, nilai tukar dan pertumbuhan ekonomi. Selain itu juga, faktor-faktor mikro ekonomi seperti kinerja keuangan, keputusan pendanaan, dan keputusan investasi berpengaruh pada nilai perusahaan. Oleh karena itu, beberapa faktor

tersebut perlu dipertimbangkan dalam memperbaiki dan memperoleh manajemen kinerja yang baik agar suatu perusahaan dapat memperoleh nilai perusahaan yang baik dari sisi keuntungan maupunperkembangannya.

Pada penelitian ini menggunakan perusahan yang tergabung dalam indeks Kompas 100 pada Bursa Efek Indonesia (BEI). Indeks Kompas 100 adalah suatu indeks saham dari 100 saham perusahaan publik yang diperdagangkan di Bursa Efek Indonesia. Saham-saham yang terpilih untukdimasukkan dalam indeks Kompas 100 ini selain memiliki likuiditas yang tinggi, serta nilai kapitalisasi pasar yang besar, juga merupakan saham-saham yang memiliki fundamental dan kinerja yang baik. Saham- saham yang termasuk dalam indeks Kompas100 diperkirakan mewakili 70$80 \%$ dari totalRp. 1.582 triliun nilai kapitalisasi pasar seluruh saham yang tercatat di BEI, maka dengan demikian investor dapat melihat kecenderungan arah pergerakan indeks dengan mengamati pergerakan Indeks Kompas 100. Berdasarkan laporan keuangan yang diobservasi mulai tahun 2015-2019 
menunjukan hasil sebagai berikut :Tabel 1. Struktur Modal, Laba Bersih dan Harga Saham Kompas 100 periode 2015-2019

\begin{tabular}{|l|l|l|r|r|}
\hline Tahun & Ekuitas & Liabilitas & \multicolumn{1}{c|}{ Laba Bersih } & Harga Saham \\
\hline 2015 & $17,613,038$ & $24,309,666$ & $3,388,598$ & $5,604.04$ \\
\hline 2016 & $19,810,751$ & $25,093,260$ & $4,625,182$ & $6,141.76$ \\
\hline 2017 & $21,670,101$ & $23,625,099$ & $4,685,617$ & $6,969.04$ \\
\hline 2018 & $23,369,322$ & $26,289,278$ & $4,749,052$ & $6,182.16$ \\
\hline 2019 & $24,216,001$ & $27,845,414$ & $4,296,651$ & $5,247.67$ \\
\hline
\end{tabular}

Sumber : IDX 2015-2019 yang diolah kembali

Dari data yang terlihat pada tabel 1 dari tahun 2015-2019 menunjukan penggunaan sumber dana yang berasal dari modal sendiri terus meningkat dari tahun 2015 sebesar 17,613,038 menjadi 24,216,001 pada tahun 2019. Demikian juga dengan modal yang bersumber dari hutang juga terjadi peningkatan dari 24,309,666 tahun 2015 menjadi 27,845,414 tahun 2019 walaupun sempat terjadi penurunan pada tahun 2017. Peningkatan struktur modal baik yang bersumber dari ekuitas dan liabilitas tidak sejalan dengan peningkatan laba bersih dan harga saham di Bursa Efek. Laba bersih yang dihasilkan cendrung berfluktuasi dari tahun 2015-2019, begitu juga harga saham yang terjadi penurunan dari tahun 2018 sampai dengan 2019. Oleh karena itu perlu dilihat bagaimana struktur modal berpengaruh terhadap keputusan manajemen perusahaan yang akan berdampak bagi nilaiperusahaan.

\section{TINJAUAN PUSTAKA}

\section{Nilai Perusahaan}

Rasio penilaian perusahaan berkaitan langsung dengan tujuan memaksimalkan nilai perusahaan dankekayaan para pemegang saham. Rasio penilaian perusahaan yang digunakan adalah market value ratio yang terdiri dari 3 macam rasio yaitu price earnings ratio, price/cash flow ratio dan price to book value ratio. Price earnings ratio adalah rasio harga per lembar saham terhadap laba per lembar saham. Dalam masing-masing nilai pada rasio ini menunjukkan berapa banyak jumlah rupiah yang harus dibayarkan oleh para investor untuk membayar setiap rupiah laba yang dilaporkan. Price/cash flow ratio adalah harga per lembar saham dibagi dengan aruskas per lembar saham. Sedangkan Priceto book value ratio adalah suatu rasio yang menunjukkan hubungan antara harga pasar saham perusahaan dengan nilai buku perusahaan (Weston \& Copeland, 1997). Rasio PBV mengukur sejauh mana kemampuan perusahaan menciptakan nilai relatif terhadap jumlah modal yang diinvestasikan dan menghitung harga saham yang dibagi dengan jumlah dari ekuitas (Sartono, 2001). Semakin tinggi harga saham, semakin berhasil perusahaan menciptakan nilai bagi pemegang saham. Keberhasilan perusahaan menciptakan nilai tersebut memberikan harapan kepadapemegang saham berupa keuntungan yang lebih besar pula (Sartono,2001). 
PBV didefinisikan sebagai hargapasar suatu saham dibagi dengan book value nya (BV) (Najmiyah, 2014). PBV juga digunakan untuk mengukur nilai suatu saham. Semakin tinggi PBV, maka semakinmahal harga sahamnya. PBV juga menunjukkan seberapa jauh perusahaan mampu menciptakan nilai perusahaan. Perusahaan yang berjalan baik umumnya mempunyai PBV diatas satu, yang menunjukkan nilai pasar lebih tinggi dari nilai buku nya. Semakin tinggi PBV semakin tinggi pula return saham. Semakin tinggi return saham akan menambah pendapatan perusahaan sehingga meningkatkan kemampuan perusahaan untuk membagikan dividen.

\section{Suku Bunga}

Bunga dapat diartikan sebagai hargayang harus dibayar oleh perusahaan dan/atau nasabah sebagai balas jasa atas transaksi antara perusahaan dan nasabah. Dalam perusahaan, terdapat dua harga yaitu harga beli dan jual. Apabila perusahaan membeli dana dari nasabah, maka perusahaan akan membayar sejumlah harga tertentu kepada nasabah, oleh karena itu dapat dikatakan bahwa perusahaan akan membeli dana dari nasabah dengan harga beli tertentu yang disebut dengan bunga simpanan. Disisi lain, perusahaan juga akan menjual dana kepada nasabah yang membutuhkan dana dengan harga jual tertentu yang diperjanjikan. Harga tersebut merupakan harga jual perusahaan kepadanasabah. Perbedaan harga jual dan beli yang diaplikasikan dengan adanya perbedaan bunga kredit dan simpanan disebut dengan spread (Ismail, 2010). Penerapan bunga yang terdapat pada perusahaan konvensionaldapat dipisahkan menjadi dua jenis (Ismail, 2010) yaitu:

a. Bunga Simpanan

b. Bunga Pinjaman

Naik atau turunnya suku bunga dapat mempengaruhi nilai perusahaan. Naiknya suku bunga berpengaruh terhadap penurunan daya beli masyarakat terhadap produk yang dihasilkan oleh industri- industri. Turunnya daya beli terhadap produk dapat menurunkan laba yang dihasilkan perusahaan sehingga menurunkan nilai dari perusahaan. Selain itudari pihak industri yang mengandalkan modal dari pinjaman perbankan kenaikan suku bunga akan menambah beban produksi dan dapat mengurangi laba perusahaan. Penurunan laba yang dihasilkan akan menurunkan nilai dari perusahaan dikarenakan investor tidak tertarik menanamkan modal pada perusahaan pada saat naiknya suku bunga. Hasil penelitian Noviyanti, V., Mardani, R. M., \& Wahono, B. (2019), tingkat suku bunga SBI berpengaruh positif terhadap nilai perusahaan manufaktur sektor makanan dan minuman yang terdaftar di BEI tahun 2014-2017. Kenaikan suku bunga akan mempengaruhi nilai sekarang (present value) aliran kas perusahaan sehingga kesempatan-kesempatan investasi yang ada tidak akan menarik lagi. Kenaikan suku bunga juga akan meningkatkan biaya modal yang harus ditanggung perusahaan dan jugaakan menyebabkan return yang disyaratkaninvestor dari suatu investasi akan meningkat. Perubahan suku bunga bisa mempengaruhi variabilitas return suatu investasi. Perubahan suku bunga akan mempengaruhi harga saham secara terbalik. Artinya, jika suku bunga meningkat, maka harga saham akan turun. 
Tingkat bunga yang tinggi merupakan sinyal negatif terhadap harga saham. Tingkat suku bunga yang meningkatakan menyebabkan peningkatan suku bunga yang disyaratkan atas investasi pada suatu saham perusahaan. Disamping itu tingkat suku bunga yang meningkat bisa juga menyebabkan investor menarik investasinya pada saham dan memindahkannya pada investasi berupa tabungan ataupun deposito (Tandelilin, 2010). Naik turunnya suku bunga tersebut kemudian juga berpengaruh pada nilai perusahaan dimana untuk mengetahui bagaimana tingkat suku bunga berperan bagi kinerja keuangan.

\section{H1: Suku Bunga berpengaruh negatif terhadap nilai perusahaan. Nilai Tukar}

Nilai tukar mata uang atau sering disebut dengan kurs adalah harga satu unit mata uang asing dalam mata uang domestikatau dapat juga dikatakan harga mata uang domestik terhadap mata uang asing atau nilaitukar terhadap dolar (Firdaus, 2011). Exchange Rates (nilai tukar uang) atau yangdikenal dengan sebutan kurs mata uang adalah catatan harga pasar dari mata uang asing dalam harga mata uang domestik atau resiprokalnya yaitu harga mata uang domestik dalam mata uang asing. Nilai tukar uang merepresentasikan tingkat harga pertukaran dari satu mata uang ke mata uang yang lainnya dan digunakan dalam berbagai transaksi, antara lain transaksi perdagangan internasional, turisme, investasi internasional, ataupun aliran uang jangka pendek antar negara, yang melewati batas- batas geografis ataupun batas-batas hukum (Arif, 2010). Terdapat tiga macam sistem nilai tukar mata uang (Arif, 2010) sebagai berikut:

a. Sistem Nilai Tukar Tetap (FixedExchange Rate System)

b. Sistem Nilai Tukar Mengambang (Floating Exchange Rate System)

c. Sistem Nilai Tukar Yang Dikaitkan (pegged exchange rate system) yaitu nilai mata uang ditetapkan dengan jalan mengaitkan mata uang suatu negara dengan mata uang negara lain atau sejumlah mata uang tertentu yang biasanya merupakan mata uang kuat (hard currency).

Nilai tukar digunakan untuk menjembatani perbedaan antara mata uang di masing- masing negara sehingga perdagangan diantara dua negara atau lebih yang memiliki mata uang yang berbeda dapat melakukan transaksi ekonomi. Apabila rupiah melemahdan Dollar menguat maka hal ini membuat investor lebih memilih untuk berinvestasi dalam bentuk dollar dibandingkan dengan berinvestasi pada surat-surat berharga, hal tersebut akan mengurangi minat investor untuk membeli saham sehingga berdampak pada return perusahaan (Tendelilin, 2010). Apabila terjadi inflasi yang melonjak naik dinegara asing sedangkan di dalam negeri relatif stabil, maka harga barang dari negara asing akan mengalami kenaikan. Kondisi ini akan menurunkan permintaan terhadap barang asing dan akan menaikkan permintaan terhadap barang domestik. Akibatnya, nilai mata uang domestik akan naik terhadap mata uang asing yang menyebabkan daya saing barang domestik di pasar ekspor akan menurun karena di luar negeri harganya menjadi mahal. Sebaliknya, apabila mata uang domestik menurun terhadap mata uang asing 
sehingga menyebabkan meningkatnya permintaan terhadap barang domestik oleh negara asing,berarti akan meningkatkan cash flow pada perusahaan domestik kemudian meningkatkan harga saham perusahaan dan dapat meningkatkan kinerja keuangan perusahaan (Tandelilin, 2010).

\section{$\mathrm{H}_{2}$ : Nilai Tukar berpengaruh positif terhadapnilai perusahaan. Pertumbuhan Ekonomi (PDB)}

Pengertian pertumbuhan ekonomi merupakan perkembangan kegiatan yang menyebabkan adanya peningkatan jumlahproduksi barang dan jasa di suatu negara. Arti pertumbuhan sendiri secara umum adalah ungkapan yang menggambarkan adanya tingkat perkembangan. Dari sini, bisa dipahami pula bahwa pertumbuhan ekonomi ini digunakan untuk mengukur prestasi yang dicapai dalam perkembangan suatu perekonomian. Pertumbuhan ekonomi daerah berkaitan dengan Produk Domestik Bruto (PDB). Produk domestik merupakan Semua barang dan jasa sebagai hasil dari kegiatan-kegiatan ekonomi yang beroperasi di wilayah domestik, tanpa memperhatikan apakah faktor produksinya berasal dari atau dimiliki oleh penduduk daerah tersebut (Todaro, 2011). Menurut Kuncoro (2004), pertumbuhan ekonomi adalah proses kenaikan output per kapita dalam jangka panjang, disini proses mendapat penekanan karena mengandung unsur dinamis dandapat dihitung:

$$
\mathrm{g}=\frac{\mathrm{Y}_{t}-\mathrm{Y}_{t-1}}{\mathrm{Y}_{t-1}} \mathrm{X} 100 \%
$$

Pertumbuhan ekonomi merupakan perkembangan kegiatan yang menyebabkan adanya peningkatan jumlah produksi barang dan jasa di suatu negara. Arti pertumbuhan sendiri secara umum adalah ungkapan yang menggambarkan adanya tingkat perkembangan. Dapat difahami bahwa pertumbuhan ekonomi ini digunakan untuk mengukur prestasi yang dicapai dalam perkembangan suatu perekonomian. Pertumbuhan ekonomi daerah berkaitan dengan Produk Domestik Bruto (PDB). Produk domestik merupakan Semua barang dan jasa sebagai hasil dari kegiatan-kegiatan ekonomi yang beroperasi di wilayah domestik, tanpa memperhatikan apakah faktor produksinya berasal dari atau dimiliki oleh penduduk daerah tersebut (Todaro,2011). Pertumbuhan ekonomi berkesinambungan adalah pertumbuhan ekonomi yang terus berlangsung dalam jangka panjang, yang didasarkan atas tabungan, investasi, serta kegiatan swasta dan publik yang saling melengkapi. Produk domestik bruto adalah ukuran produksi barang dan jasa total suatu negara. Pertumbuhan Produk domestik bruto yang cepat merupakan indikasi terjadinya pertumbuhan ekonomi. Jika pertumbuhan ekonomi membaik, maka daya beli masyarakat pun akan meningkat, dan ini merupakan kesempatan bagi perusahaan- perusahaan untuk meningkatkan kinerja keuangannya. Dengan meningkatnya kinerja keuangan karena nilai PDB yang meningkat karena kontribusi pertumbuhan ekonomi dan kemudian otomatis akan meningkatkan nilai perusahaan yang berkontribusi pada perkembangan eksistensi perusahaan dan kinerjanya, maka kesempatan perusahan memperoleh keuntungan juga akan semakin meningkat. Meningkatnya PDB merupakan sinyal yang baik (positif) untuk investasi dansebaliknya jika PDB menurun akan memberikan dampak 
negatif yang otomatis berpengaruh pada nilai perusahaan. Meningkatnya pertumbuhan ekonomi yang berdampak pada PDB mempunyai pengaruh positif dikarenakan meningkatnya pertumbuhan ekonomi dan karena PDB naik maka meningkatnya terhadap daya beli konsumen sehingga dapat meningkatkan permintaan terhadap produk perusahaan(Tandelilin, 2010).

\section{H3: Pertumbuhan ekonomi berpengaruh positif terhadap nilai perusahaan.}

\section{Kinerja Keuangan (Return On Equity)}

Return on equity (ROE) adalah rasio yang mengukur kemampuan perusahaan memperoleh laba yang tersedia bagi pemegang saham perusahaan. ROE mengukur kemampuan perusahaan untuk memperoleh laba yang tersedia bagi pemegang saham perusahaan. Rasio ini dipengaruhi oleh besar kecilnya hutang perusahaan, apabila proporsi hutang makin besar maka rasio ini juga akan makin besar (Sartono, 2001). Semakin tinggi ROE menunjukan semakin efisien perusahaan menggunakan modal sendiri untukmenghasilkan laba atau keutungan bersih (Robert Ang, 2001). Rasio ini merupakan indikator yang amat penting bagi para pemegang saham dan calon investor untuk mengukur kemampuan perusahaan dalam memperoleh laba bersih yang dikaitkan dengan pembayaran deviden. Kenaikan dalam rasio ini berarti terjadi kenaikan laba bersih dari perusahaan yang bersangkutan. Selanjutnya kenaikan tersebut akan mengakibatkan kenaikan harga saham(Dendawijaya, 2003). Berikut ini cara menghitung ROE (Sartono, 2001):

$$
=\frac{\text { ROE }}{\text { Ekuitas (pemegang Saham) }} \text { X100\% }
$$

Kenaikan dalam rasio ini berart terjadi kenaikan laba bersih dari perusahaanyang bersangkutan. Return On Equity (ROE) merupakan rasio keuangan yang banyak digunakan untuk mengukur kinerja keuangan perusahaan, khususnya menyangkut profitabilitas perusahaan. Dari sudut pandang pemilik suatu perusahaan, Return On Equity (ROE) merupakan suatu ratio yang harus diperhatikan. Oleh karena itu, sudah seharusnya pihak manajemen memberikan perhatian pada sudut pandang pemilik perusahaan dan harapan mereka berkaitan dengan jangka waktu dan pelaksanaan. Hal ini merupakan dasar bagi pertambahan nilai (value creation) bagi pemegang saham. Return On Equity (ROE) mengukur tingkat pengembalian kepada pemegang saham perusahaan dan diperoleh setelah dikurangi pengembalian yang dibayarkan kepada kreditur (bunga). Keuntungan yang akan diraih dari investasi yang akan ditanamkan merupakan pertimbangan utama bagi sebuah perusahaan dalam rangka pengembangan dan kemudiandinilai pada nilai perusahaan (PBV) pula. 


\section{$\mathrm{H}_{4}$ : Kinerja Keuangan (ROE) berpengaruh positif terhadap nilai perusahaan. Keputusan Pendanaan (Total Debt Ratio)}

Total debt ratio digunakan untuk mengukur seberapa besar perusahaan mengandalkan hutang untuk membiayai asetnya. Rasio hutang ini dapat menunjukanproporsi hutang perusahaan terhadap total aset yang dimilikinya. Para investor dapat menggunakan Rasio Hutang atau Debt Ratio ini untuk mengetahui berapa banyak hutangyang dimiliki oleh perusahaan dibandingkan dengan asetnya. Kreditur juga dapat mengukur seberapa tinggi risiko yang diberikan kepada suatu perusahaan. Semakintinggi rasionya, semakin besar pula risiko yang terkait dengan operasional perusahaan. Sedangkan rasio utang yang rendah mengindikasikan pembiayaan konservatif dengan kesempatan untuk meminjam dimasa depan tanpa risiko yang signifikan. Rendahnya rasio hutang juga memiliki arti hanya sebagian kecil aset perusahaan yang dibiayai dari hutang. Rasio hutang (DebtRatio) hampir sama dengan rasio hutang terhadap Ekuitas, hanya saja dihitung dalam cara yang berbeda. Berikut ini rumus TDR (Sartono, 2001):

$$
\text { TDR }=\frac{\text { Total Utang }}{\text { aktiva }} \times 100 \%
$$

Rasio profitabilitas dengan TDR termasuk dalam rasio solvabilitas dan dapat menjadi indikator keputusan pendanaan. Rasio ini merupakan rasio yang digunakan untuk mengukur kemampuan perusahaan dalam membayarkan seluruh kewajiban yang dimilkinya pada saat perusahaan dilikuidasi. TDR ini dapat menjadi alat ukuruntuk mengetahui seberapa besar seluruhaktiva perusahaan itu dibiayai dari total hutangnya. Jika perusahaan mempunyai nilai TDR yang semakin tinggi, maka jumlahmodal pinjaman dari perusahaan akan ikut tinggi dan otomatis nilai perusahaan juga terpengaruh. Namun, apabila dari jumlah modal pinjaman yang besar tersebut tidak dapat mengembalikan atau menghasilkan keuntungan bagi perusahaan, maka pada saat perusahaan dilikuidasi kemungkinan besar perusahaan tersebut tidak dapat mengembalikan modal pinjaman seluruhnya dan nilai TDR juga terpengaruh.

\section{H5: Keputusan Pendanaan (TDR) berpengaruh positif terhadap nilai perusahaan.} Keputusan Investasi (Pertumbuhan Aktiva Tetap)

Pertumbuhan aktiva dapat disebutjuga dengan pertumbuhan sumber ekonomi yang diharapkan memberikan manfaat usaha di kemudian hari. Aset dimasukkan dalam neraca dengan saldo normal debit. Perusahaan dengan tingkat pertumbuhan yang lebih cepat maka harus lebih mengandalkan sumber dana dari luar perusahaan. Menurut Walmiaty (2008), pertumbuhan perusahaan menjadi salah satu tanda dalam menilai kemampuan perusahaan untuk membayar utang- utangnya dan kemudahan perusahaan untuk memperoleh pendanaan eksternal. Struktur aktiva adalah proporsi investasi perusahaan dalam bentuk aktiva tetap. Aktiva tetap adalah aktiva yang mempunyai umur kegunaan relatif permanen atau jangka panjang. Menurut Walmiaty ( 2008), Struktur aktiva adalah investasi dari perusahaan dalam 
bentuk aktiva tetap yang dapat diukur dengan perbandingan antaraaktiva tetap dan total aktiva perusahaan, struktur aktiva dapat dijadikan jaminan bagi investor agar investor tersebut percaya bahwa perusahaan dapat melunasi utangnya. Berikut ini cara menghitung pertumbuhan aktiva tetap (Riyanto, 2011):

Perusahaan $\quad$ yang $\quad$ PAT $=\frac{\text { Tat }- \text { Tat }-1}{\text { Tat }-1} \times 100 \%$ struktur aktivanya bersifat fleksibel, cenderung menggunakan leverage yang bersifat fleksibel juga, dimana memiliki kecenderungan dalammenggunakan leverage yang lebih besar daripada perusahaan yang struktur aktivanya tidak bersifat fleksibel. Perusahaan yang memiliki tingkat pertumbuhan yang cepat harus lebih banyak mengandalkan pada modal eksternal. Dengan demikian, pertumbuhan aktiva yang tinggi memiliki kecenderungan lebih banyak dalam menggunakan hutang dibanding yang lambat pertumbuhannya. Dengan demikian, pertumbuhan aktiva berhubungan dengan nilai perusahaan dimana pertumbuhan aktiva tetap ini digunakan untuk aktivitas operasional perusahaan yang berpengaruh pada nilai perusahaan, dimana untuk mengetahui laba atau keuntungan perusahaan agar dapat semakin meningkatkan kinerja perusahaan yang padaakhirnya meningkatkan nilai perusahaan.

\section{$\mathrm{H}_{6}$ : Keputusan Investasi (Pertumbuhan Aktiva Tetap) berpengaruh positif terhadap nilai perusahaan.}

\section{METODE PENELITIAN}

Tabel 2. Hasil Uji F

\begin{tabular}{|l|l|}
\hline -Statistic & Prob (F-statistic) \\
\hline 7,01 & 0,000001 \\
\hline \multicolumn{2}{|c|}{ Sumber: Data sekunder diolah } \\
\hline
\end{tabular}

\section{Uji Parsial (Uji t)}

Uji t digunakan untuk mengujiapakah tiap-tiap variabel independen secara parsial memiliki pengaruh terhadap variabel dependen. Pengujian menggunakan uji

Tabel 3.. Hasil Uji t

\begin{tabular}{lllll}
\hline Variable & Coefficient & $\begin{array}{l}\text { Std. } \\
\text { Erro } \\
\text { r }\end{array}$ & t-Statistic & Prob. \\
\hline C & 1274.07 & 794.76 & 1.60 & 0.11 \\
Suku Bunga & -23.69 & 21.15 & -1.12 & 0.26 \\
Nilai Tukar & 0.01 & 0.03 & 0.33 & 0.75 \\
Pertumbuhan Ekonomi & -200.82 & 181.84 & -1.10 & 0.27 \\
Kinerja Keuangan & 2.33 & 0.41 & 5.64 & 0.00 \\
Keputusan Pendanaan & -1.65 & 0.53 & -3.10 & 0.00 \\
Keputusan Investasi & 0.41 & 0.22 & 1.87 & 0.06 \\
\hline
\end{tabular}

Sumber: Data sekunder diolah

Hasil analisis dapat dilihat pada Tabel 4.8yang dijelaskan. Hipotesis pertama $\left(\mathrm{H}_{1}\right)$ 
Berdasarkan sifat eksplanasi ilmu penelitian ini merupakan penelitian asosiatif. Asosiatif dapat didefinisikan sebagai penelitian yang bertujuan menjelaskan hubungan dua variabel atau lebih yang sifatnya sebab akibat (kasualitas) (Wijaya 2013). Selain itu juga jenis penelitian ini menggunakan penelitian kuantitatif, dimana penelitian yang bertujuan untuk mengetahui pengaruh antar variabel. Populasi dalam penelitian ini adalah perusahaan yang terdaftar di BEI pada indeks Kompas 100 periode tahun 2015-2019. Sampel dalam penelitian ini adalah sebagai berikut :

1. Perusahaan non perbankan yang tergabung pada indeks Kompas 100 berjumlah 92 perusahaan.

2. Aktif selama 5 tahun berturut-turut dari periode $2015-2019$ berjumlah 51 perusahaan.

\section{HASIL DAN PEMBAHASAN}

\section{Hasil Regresi ModelUji F}

Uji $\mathrm{F}$ digunakan untuk menguji apakah variabel independen secara simultan (bersama-sama) berpengaruh terhadap variabel dependen. Dari tabel 4.8 dapat diketahui bahwa nilai probabilitas F-statistic sig. $=0.000001<0,05$, maka dapat disimpulkan bahwa variabel suku bunga, nilaitukar, pertumbuhan ekonomi, kinerja keuangan, keputusan pendanaan dan keputusan investasi secara bersama-sama mempunyai pengaruh yang signifikanterhadap nilai perusahaan. $<0.05$. maka $\mathrm{H} 0$ ditolak dan $\mathrm{Ha}$ diterima yang berarti secara parsial variabel independen berpengaruh signifikan terhadap variable. menyatakan bahwa suku bunga berpengaruh negatif dan signifikan terhadap nilai perusahaan. Hasil uji t menunjukkan sukubunga memiliki nilai koefisien -23,69, $t_{\text {hitung }}$ sebesar 1,12 dan nilai probabilitas sebesar 0,26 . Karena $t$ hitung bersifat negatif dan lebih kecil dari $t$ tabel yakni $-1,12<1,65259$ dan nilai probabilitas lebih besar dari $\alpha=0,05$ $(0,26>0,05)$, dengan demikian hipotesis pertama $\left(\mathrm{H}_{1}\right)$ ditolak. Hipotesis kedua $\left(\mathrm{H}_{2}\right)$ menyatakan bahwa nilai tukar berpengaruh positif dan signifikan terhadap nilai perusahaan. Hasil uji t menunjukkan nilaitukar memiliki nilai koefisien $0,01, t_{\text {hitung }}$ sebesar 0,33 dan nilai probabilitas sebesar 0,75. Karena thitung bersifat positif dan lebih kecil dari tabel yakni 0,33<1,65259 dan nilai probabilitas lebih besar dari $\alpha=$ $0,05(0,75>0,05)$, dengan demikian hipotesis kedua $\left(\mathrm{H}_{2}\right)$ ditolak. Hipotesis ketiga $\left(\mathrm{H}_{3}\right)$ menyatakan bahwa pertumbuhan ekonomi berpengaruh positif dan signifikan terhadap nilai perusahaan. Hasil uji $\mathrm{t}$ menunjukkan pertumbuhan ekonomi memiliki nilai koefisien $-200,82$, $t_{\text {hitung }}$ sebesar $-1,10$ dan nilai probabilitas sebesar 0,27 . Karena $t_{\text {hitung }}$ bersifat negatif dan lebih kecil dari tabel yakni

$-1,10<1,65259$ dan nilai probabilitas lebih besar dari $\alpha=0,05(0,27>0,05)$. Dengan demikian hipotesis ketiga $\left(\mathrm{H}_{3}\right)$ ditolak.

Hipotesis keempat $\left(\mathrm{H}_{4}\right)$ menyatakan bahwa kinerja keuangan berpengaruh positif dan signifikan terhadap nilai perusahaan. Hasil uji t menunjukkan kinerja keuangan memiliki nilai koefisien 2,33, thitung sebesar 5,64 dan nilai probabilitas sebesar 0,00. Karena $t_{\text {hitung }}$ bersifat positif dan lebih besar dari $t_{\text {tabel }}$ yakni 5,64>1,65259 dan nilai 
probabilitas lebih kecil dari $\alpha=0,05(0,00<0,05)$. Dengan demikian hipotesis keempat $\left(\mathrm{H}_{4}\right)$ diterima. Hipotesis kelima $\left(\mathrm{H}_{5}\right)$ menyatakan bahwa keputusan pendanaanberpengaruh positif dan signifikan terhadap nilai perusahaan. Hasil uji t menunjukkan keputusan pendanaan memiliki nilai koefisien -1,65, thitung sebesar 3,10 dan nilai probabilitas sebesar 0,00 . Karena thitung bersifat negatif dan lebih besar dari tabel yakni $-3,10>1,65259$ dan nilai probabilitas lebih kecil dari $\alpha=0,05$ $(0,00<0,05)$. Dengan demikian hipotesis kelima $\left(\mathrm{H}_{5}\right)$ diterima. Hipotesis keenam $\left(\mathrm{H}_{6}\right)$ menyatakan bahwa keputusan investasi berpengaruh positif dan terhadap nilai perusahaan. Hasil uji t menunjukkan keputusan investasi memiliki nilai koefisien 0,41 , $t_{\text {hitung }}$ sebesar 1,87 dan nilai probabilitas sebesar 0,06 . Karena $t_{\text {hitung }}$ bersifat positif dan lebih besar dari $t_{\text {tabel }}$ yakni 1,87>1,65259 dan nilai probabilitas lebih besar dari $\alpha=0,05(0,06>0,05)$. Dengan demikian hipotesis keenam $\left(\mathrm{H}_{6}\right)$ ditolak.

\section{Uji Koefisien Determinasi $\left(\operatorname{Adj} \mathbf{R}^{2}\right)$}

Coefficient of Determination $\left(\mathrm{R}^{2}\right)$ digunakan untuk mengukur proporsi penurunan variabilitas $\mathrm{Y}$ sebagai akibat pengunaaan variabel-variabel bebas di dalam model regresi. Nilai $\mathrm{R}^{2}$ yang kecil berati kemampuan variabel-variabel independen dalam menjelaskan variasi variabel independen amat terbatas. Jika dalam uji empiris didapatkan nilai adjusted $\mathrm{R}^{2}$ negatif. maka nilai adjusted $\mathrm{R}^{2}$ dianggap bernilai nol. Berikut nilai koefisien determinasi:

Tabel 4. Hasil Uji Koefisien Determinasi

\begin{tabular}{|l|l|}
\hline$R$-squared & 0,14 \\
\hline
\end{tabular}

Sumber: Data sekunder diolah

Koefisien determinasi $\left(\mathrm{R}^{2}\right)$ padaintinya mengukur seberapa jauh kemampuanmodel dalam menerangkan variasi variabel dependen. Nilai koefisien determinasi adalah antara nol dan satu. Nilai yang kecil berarti kemampuan variable-variabel independen dalam menjelaskan variable-variabel dependen amat terbatas. Nilai yang mendekati satu berarti variabel-variabel independen memberikan hampir semua informasi yang dibutuhkan untuk memprediksi variasi variabel dependen (Ghozali, 2013). Pada tabel 4.11 menunjukan nilai R-Squared sebesar 0.14 yang menunjukan bahwa sebesar $14 \%$ nilai perusahaan dapat dijelaskan oleh variabel suku bunga, nilai tukar, pertumbuhan ekonomi, kinerja keuangan, keputusan pendanaan dan keputusan investasi sedangkan sisanya sebesar $86 \%$ dijelaskan oleh variabel yang lain yang tidak ditelitidipenelitian ini.

\section{Pembahasan}

\section{Pengaruh Suku Bunga Terhadap NilaiPerusahaan}

Hasil analisis menunjukkan nilai koefisien beta -23,69. Hasil temuan dalam penelitian ini menunjukan arah koefisien negatif yang memberikan hubungan bahwa ketika suku bunga mengalami penurunan maka nilai perusahaan akan meningkat. Pengaruh negatif suku bunga sesuai dengan teori yang dingkapkan oleh 
Tandelilin (2000) dan Madura (2006) yang menyatakan bahwa faktor-faktor ekonomi makro, seperti laju pertumbuhan inflasi, tingkat suku bunga dan fluktuasi nilai tukar mata uang (exchange rate) secara empirik telah terbukti mempunyai pengaruh terhadap kondisi pasarmodal dibeberapa negara.

Fenomena hubungan ini dapatterjadi disebabkan oleh kondisi ekonomi global yang sedang mengalami pelambatan mulai berdampak pada perekonomian Indonesia, hal ini terlihat dari tren nilai perusahaan (PBV) yang menurun sejak tahun 2015 sampai tahun 2019. Sehingga walaupun BI rate telah diturunkan namun kinerja perusahaan belum dapat pulih akibat tingkat penjualan perusahaan-perusahaan sedang mengalami penurunan.

Adapun nilai signifikansi yang ditemukan dalam penelitian ini adalah sebesar 0,26 yang menandakan bahwa suku bunga tidak berpengaruh signifikan terhadap nilai perusahaan. Tidak berpengaruh suku bunga terhadap nilai perusahaan dikarenakan manajemen kurang meresponpenyesuaian struktur modal yang dapat mempengaruhi profit perusahaan. Hal ini dapat dilihat dari tabel 5 :

Tabel 5. Rata-Rata Suku Bunga, Struktur Modal dan Nilai Perusahaan Tahun 2015-2019

\begin{tabular}{|c|c|c|c|c|}
\hline \multirow{2}{*}{ Tahun } & \multirow{2}{*}{$\begin{array}{ll}\text { Suku } & \\
& \text { Bung } \\
\mathrm{a}(\%) & \end{array}$} & \multirow{2}{*}{$\begin{array}{l}\text { Nilai } \\
\text { Perusahaa } \\
\text { n }\end{array}$} & \multicolumn{2}{|c|}{ Struktur Modal (\%) } \\
\hline & & & Ekuitas & Liabilitas \\
\hline 2015 & 7.50 & 2.17 & 42 & 58 \\
\hline 2016 & 5.67 & 2.06 & 44 & 56 \\
\hline 2017 & 4.56 & 2.35 & 48 & 52 \\
\hline 2018 & 5.06 & 2.04 & 47 & 53 \\
\hline 2019 & 5.63 & 1.88 & 47 & 53 \\
\hline
\end{tabular}

Sumber: Data sekunder diolah

Dari tabel 5 menunjukan penurunan suku bunga dari tahun 2015 sampai tahun 2017. Penurunan suku bunga tersebut dapat dimanfaatkan perusahaan untuk meningkatkan profit dari penggunaan modal yang bersumber dari hutang. Namun dari tabel diatas menunjukan perusahaan tidak meningkatkan penggunaan modal yangbersumber dari hutang. Dapat dilihat pada tahun 2015 modal yang bersumber dari hutang $58 \%$ menurun menjadi 52\% pada tahun 2017. Bahkan peningkatan suku bunga dari tahun 2017 sampai 2019 diikuti peningkatan modal dari hutang. Dari permasalahan tersebut berdampak mengurangi profit perusahaan sehingga minat investor menurun yang pada akhirnya menurunkan harga saham yang mencerminkan nilai dari perusahaan selamaperiode penelitian. Penelitian ini tidak sejalan dengan penelitian yang dilakukan oleh Subagyo, et al (2018) yang menyatakan bahwa tingkat suku bunga Bank Indonesia berpengaruh signifikan terhadap nilai perusahaan. Yang berarti bahwa tinggi rendahnya suku bunga sangat berpengaruh pada nilai perusahaan.

Tingkat bunga pada umumnya digunakan sebagai ukuran biaya modal yangharus 
dikeluarkan untuk memperoleh dana tersebut dari para pemilik modal (kreditur). Tingkat bunga ini disebut dengan bunga pinjaman (Iswardono,1999). Oleh karenaitu, tingkat bunga sebenarnya merupakan harga yang bersedia untuk dibayar oleh masyarakat yang membutuhkan uang (debitur), tingkat bunga ini terbentuk dipasar uang dan pasar modal. Dilihat dari perspektif perusahaan, tingkat bunga merupakan komponen biaya modal bagi perusahaan, sehingga naiknya tingkat suku bunga ini merupakan tambahnya beban biaya yang harus ditanggung oleh perusahaan. Dengan demikian ketika tingkat bunga meningkat manajemen akan merespon dengan menyesesuaikan tingkat struktur modalnya untuk mengungurangi beban finansial yang harus dibayarkan.

\section{Pengaruh Nilai Tukar Terhadap Nilai Perusahaan}

Hasil analisis menunjukkan nilai koefisien beta 0,01. Hasil temuan dalam penelitian ini menunjukan arah koefisien positif yang memberikan pengaruh bahwa ketika nilai tukar mengalami peningkatan maka nilai perusahaan akan meningkat. Adapun nilai signifikansi yang ditemukan dalam penelitian ini adalah sebesar 0,75 yang menandakan bahwa nilai tukar tidak berpengaruh signifikan terhadap nilai perusahaan. Tidak adanya pengaruh yangsignifikan dari nilai tukar terhadap nilai perusahaan dalam penelitian ini disebabkan karena nilai tukar tidak terlalu berpengaruh terhadap biaya dan volumepenjualan perusahaan. Dapat dilihat tabel dibawah ini :

Tabel 6. Rata-Rata Nilai Tukar dan Laba Bersih Perusahaan Tahun 2015-2019

\begin{tabular}{lrr} 
Tahun & Nilai Tukar & Laba Bersih \\
\hline 2015 & 13,795 & $3,388,598$ \\
2016 & 13,436 & $4,625,182$ \\
2017 & 13,548 & $4,685,617$ \\
2018 & 14,481 & $4,749,052$ \\
2019 & 13,901 & $4,296,651$ \\
\hline
\end{tabular}

Sumber: Data sekunder diolah

Pada table 6 menunjukkan perusahaan tidak terlalu sensitif terhadap nilai tukar yang terjadi. Meskipun terjadi peningkatan (depresiasi) nilai tukar pada tahun 2018 tetapi laba yang dihasilkan perusahaan tidakturun. Produk-produk yang dihasilkan tetap memberikan peningkatan laba perusahaan, sehingga tidak menurunkan volume penjualan dan labanya. Selain itu kemunngkinan perusahaan menggunakan bahan baku yang bersumber dari dalam negeri, bukan barang impor. Hasil penelitian ini mendukung hasil penelitian Idamiharti (2017) yang menemukan bahwa nilai tukar tidak berpengaruh terhadap nilai perusahaan.

\section{Pengaruh Pertumbuhan Ekonomi Terhadap Nilai Perusahaan}

Hasil analisis menunjukkan nilai koefisien beta -200.82. Hasil temuan dalam penelitian ini menunjukan arah koefisien negatif yang memberikan pengaruh bahwa ketika pertumbuhan ekonomi menurun makanilai perusahaan menjadi naik. Adapun nilai signifikansi yang ditemukan dalam penelitian ini adalah sebesar 0,27 yang 
menandakan bahwa pertumbuhan ekonomi tidak berpengaruh signifikan terhadap nilai perusahaan. Penelitian ini tidak sejalandengan penelitian yang dilakukan oleh Sartika (2019), yang menyatakan bahwa PDB berpengaruh negatif dan signifikan terhadap nilai perusahaan. Peningkatan pertumbuhan ekonomi suatu negara mengindikasikan adanya peningkatankesejahteraan masyarakat di negara tersebut. Adanya peningkatan kesejahteraan masyarakat akan mendorong masyarakat untuk melakukan konsumsi terhadap barang dan jasa sehingga memperluas investasi di sektor riil. Adanya perkembangan investasi disektor riil tidak selalu diikuti adanya peningkatan investasi dipasar modal. Faktor lain yang perlu diperhatikan adalah pemerataan kesejahteraan masyarakat. Peningkatan pertumbuhan ekonomi belum tentu meningkatkan pendapatan per kapita setiap individu sehingga investasi dipasar modal tidak terpengaruh oleh adanya peningkatan pertumbuhan ekonomi. Selain itu juga target pertumbuhan ekonomi yang tidak tercapai mengindikasikan bahwa dayabeli masyarakat masih terbatas pada kebutuhan tertentu saja.

\section{Pengaruh Kinerja Keuangan TerhadapNilai Perusahaan}

Hasil analisis menunjukkan nilai koefisien beta 2.33. Hasil temuan dalam penelitian ini menunjukan arah koefisien positif yang memberikan hubungan bahwa ketika kinerja keuangan mengalami peningkatan maka nilai perusahaan akan meningkat. Pengaruh positif kinerja keuangan yang diproksikan dengan return on equity (ROE) menunjukan bahwa perusahaan mampu memanfaatkan modal yang bersumber dari investasi pemilik perusahaan dan juga hasil dari aktivitas usaha perusahaannya untuk meningkatkan kinerja keuangan perusahaan yang pada akhirnya dapat meningktakan nilai dariperusahaan. Hal ini dapat juga dilihat pada table dibawah ini :

Tabel 7. Rata-Rata Ekuitas dan Laba Bersih Perusahaan Tahun 2015-2019.

\begin{tabular}{llc} 
Tahun & Ekuitas & $\begin{array}{c}\text { Laba } \\
\text { Bersih }\end{array}$ \\
\hline 2015 & $17,613,038$ & $3,388,598$ \\
2016 & $19,810,751$ & $4,625,182$ \\
2017 & $21,670,101$ & $4,685,617$ \\
2018 & $23,369,322$ & $4,749,052$ \\
2019 & $24,216,001$ & $4,296,651$ \\
\hline
\end{tabular}

Sumber: Data sekunder diolah

Dari tabel 7 menunjukan peningkatan ekuitas dari tahun 2015 sampaitahun 2019 yang diikuti dengan peningkatan laba bersih yang dihasilkan walaupun terjadi penurunan laba bersih pada tahun 2019 namun tidak signifikan menurunkan kinerjakeuangan. Peningkatan ekuitas dapat dimanfaatkan perusahaan untuk meningkatkan profit perusahaan sehingga kinerja keuangan perusahaan dalam kondisibaik, dengan demikian maka investor akan tertarik menginvestasikan modal dan pada akhirnya dapat meningkatkan nilaiperusahaan.

Nilai signifikansi dalam penelitian ini adalah sebesar 0,00 kurang dari 0.05 yang menandakan bahwa kinerja keuangan berpengaruh signifikan terhadap nilai 
perusahaan. Signifikannya kinerja keuangan yang diproksikan ROE terhadap nilai perusahaan disebabkan karena investor menganggap bahwa secara keseluruhan rata-rata ekuitas yang dimiliki perusahaan mampu digunakan untuk menghasilkan labaperusahaan. Dengan rata-rata sebesar 16.19 menunjukkan bahwa 16.19 ekuitas mampu digunakan untuk menghasilkan laba perusahaan kedepannya dimata para investor.

\section{Pengaruh keputusan Pendanaan Terhadap Nilai Perusahaan}

Hasil analisis menunjukkan nilai koefisien beta -1.65. Hasil temuan dalam penelitian ini menunjukan arah koefisien negatif yang memberikan hubungan bahwa ketika keputusan pendanaan yang bersumberdari hutang mengalami penurunan maka nilai perusahaan akan meningkat. Pengaruh negatif keputusan pendanaan yang diproksikan dengan total debt ratio (TDR) menunjukan bahwa perusahaan masih memanfaatkan modal yang bersumber dari investasi pemilik perusahaan untuk aktivitas usaha perusahaannya untuk dapat meningkatkan nilai dari perusahaan. Dengan menurunnya penggunaan modal yang bersumber dari hutang maka nilai perusahaan akan lebih meningkat. Dalam teori pecking order yang menjelaskan mengapa perusahaan yang mempunyai tingkat keuntungan yang lebih tinggi justru mempunyai tingkat utang yang lebih kecil. Secara spesifik, perusahaan mempunyai urutan-urutan preferensi dalam penggunaan dana. Skenario urutan dalam teori pecking order adalah (1) Perusahaan memilih pandangan internal. Dana internal tersebut diperoleh dari laba (keuntungan) yang dihasilkan dari kegiatan perusahaan. (2) Perusahaan menghitung target rasio pembayaran didasarkan pada perkiraan kesempatan investasi. (3) Karena kebijakan dividen yang konstan, digabung dengan fluktuasi keuntungan dan kesempatan investasi yang tidak bisa diprediksi, akan menyebabkan aliran kas yang diterima oleh perusahaan akan lebih besar dibandingkan dengan pengeluaran investasi pada saat saattertentu dan akan lebih kecil pada saat yang lain. (4) Jika pandangan eksternal diperlukan, perusahaan akan mengeluarkan surat berharga yang paling aman terlebih dulu. Perusahaan akan memulai dengan utang, kemudian dengan surat berharga campuran seperti obligasi konvertibel, dan kemudian barangkali saham sebagai pilihanterakhir.

Dapat juga dilihat pada tabel 4.12 diatas yang menunjukkan bahwa peningkatan ekuitas dari 42 \% pada tahun 2015 menjadi 47 \% pada tahun 2019 serta penurunan hutang dari $58 \%$ pada tahun 2015 mejadi $53 \%$ pada tahun 2019 dapat berpengaruh secara signifikan terhadap nilaidari perusahaan. Hal ini sesuai dengan penelitian yang dilakukan oleh Maimunah, S., \& Hilal, S. (2018), yang menyatakan bahwa keputusan pendanaan berpengaruh signifikan terhadap nilai perusahaan. Sejalan dengan penelitian yang dilakukan oleh Nelwan, A., \& Tulung, J. E. (2018), keputusan pendanaan berpengaruh secara signifikan terhadap nilai perusahaan. Menurut Sutrisno (2003), keputusan pendanaan sering disebut dengan kebijakan struktur modal, karena dalam keputusan ini manajer keuangan dituntut untuk mempertimbangkan dan menganalisis kombinasi dari sumber-sumber dana yang ekonomis bagi perusahaan guna membelanjai kebutuhan investasi serta kegiatan usahanya. 


\section{Pengaruh Keputusan Investasi TerhadapNilai Perusahaan}

Hasil analisis menunjukkan nilai koefisien beta 0.41. Hasil penelitian ini menunjukan arah koefisien positif yang memberikan hubungan bahwa ketika keputusan investasi mengalami peningkatan maka nilai perusahaan akan meningkat. Pengaruh positif keputusan investasi yang diproksikan dengan pertumbuhan asset tettap (PAT) menunjukan bahwa ketika terdapat peningkatan asset tetap perusahaan mampu memanfaatkan untuk meningkatkan nilai dari perusahaan.

Adapun nilai signifikansi yang ditemukan dalam penelitian ini adalah sebesar 0,06 yang menandakan bahwa keputusan investasi tidak berpengaruh signifikan terhadap nilai perusahaan. Tidak berpengaruh keputusan investasi terhadap nilai perusahaan dikarenakan pertumbuhan aktiva tetap naik turun selama periode penelitian. Hal ini dapat juga dilihat pada table dibawah ini :

Tabel 8. Rata-Rata Pertumbuhan Aktiva Tetap dan Nilai Perusahaan Tahun 2015-2019

\begin{tabular}{lrc}
\hline \hline Tahun & PAT & Nilai Perusahaan \\
\hline 2015 & 28.55 & 2.17 \\
2016 & 7.17 & 2.06 \\
2017 & 4.13 & 2.35 \\
2018 & 17.27 & 2.04 \\
2019 & 7.52 & 1.88 \\
\hline \hline
\end{tabular}

Sumber: Data sekunder diolah

Dari tabel 8 menunjukan pertumbuhan aktiva tetap naik turun selama periode penelitian walaupun secara umum terlihat penurunan pertumbuhan aktiva tetap diikuti dengan penurunan nilai perusahaan dari tahun 2015 sampai dengan tahun 2019. Keputusan investasi yang dilihat dari pertumbuhan aktiva tetap yang dimiliki perusahaan dengan pilihan investasi dimasa yang akan datang tidak mampu mempengaruhi nilai perusahaan secara signifikan. Hal ini mengindikasikan bahwa, adanya investasi yang meliputi investasi dalam bentuk jangka panjang (aktiva tetap) tentunya akan banyak memberikan banyak manfaat terhadap perusahaan. Salah satunyaperusahaan dengan adanya investasi dalam bentuk jangka panjang (aktiva tetap) maka perusahaan akan dapat menambah aset yang diperlukan oleh perusahaan akan tetapi, dalam hal ini investor tentunya melihat keputusan investasi yang dilakukan perusahaan akan sangat membutuhkan banyak modal untuk melakukan pembuatan produk baru (inovasi produk), perluasan dan peningkatan penjualan, pembaharuan teknologi dan penambahan aset baru sehingga investor akan berpikir laba yang dihasilkan oleh perusahaan tidak akan dibagikan sebagai dividen tetapi akan digunakan untuk pengembanganperusahaan. Dengan demikian investasi kurang memberikan pengaruh terhadap penilaian perusahaan dimata pihak investor, meskipun keputusan investasi mampu meningkatkan dan mengembangkan perusahaan. Penelitian ini tidak sejalandengan penelitian yang dilakukan oleh Nelwan, A., \& Tulung, J. E. (2018), yang menyatakan 
bahwa keputusan investasi berpengaruh positif dan signifikan terhadap nilai perusahaan. Investasi merupakan pembelian barang (asset) hari ini tetapi digunakan untuk masa depan dalam menciptakan kekayaan. Investasi juga sebagai langkah menanamkan uang untuk memulai atau memperluas proyek atau untuk membeli aset atau bunga dimana dana-dana itu kemudian digunakan, dengan tujuan menghasilkan pendapatan dan meningkatkan nilai perusahaan seiring waktu. Teori faktor yang mempengaruhi keputusan investasi, menurut Tandelilin (2010) investasi merupakan komitmen atas sejumlah dana atau sumber daya lainnya yang dilakukan pada saat ini. Tujuannya adalah memperokeh sejumlah keuntungan dimasa yang akan datang . dalam artinya, investor menginvestasikan dana dalam bentuk-bentuk seperti saham, tanah, bangunan dengan tujuan memperoleh keuntungan di masa datang.

\section{PENUTUPAN}

\section{Simpulan}

Berdasarkan hasil penelitian yang diperoleh dan pembahasan yang telah dilakukan mengenai suku bunga, nilai tukar, pertumbuhan ekonomi, kinerja keuangan, keputusan pendanaan dan keputusan investasi terhadap nilai perusahaan pada perusahaan yang tergabung di Kompas 100 pada Bursa Efek Indonesia tahun 2015 -2019 maka dapat disimpulkan sebagai berikut :

1. Hasil pengujian hipotesis secara bersama atau simultan menunjukkan terdapat hubungan antara suku bunga, nilai tukar, pertumbuhanekonomi, kinerja keuangan, keputusan pendanaan dan keputusan investasi terhadap nilai perusahaan.

2. Hasil pengujian terdapat pengaruh negatif dan tidak signifikan suku bunga terhadap nilai perusahaan, yang memberikan hubungan bahwa ketika suku bunga mengalami penurunan maka nilai perusahaan akan meningkat.

3. Hasil pengujian terdapat pengaruh positif dan tidak signifikan nilai tukar terhadap nilai perusahaan,yang memberikan pengaruh bahwa ketika nilai tukar mengalamipeningkatan maka nilai perusahaan akan meningkat.

4. Hasil pengujian terdapat pengaruh negatif dan tidak signifikan pertumbuhan ekonomi terhadap nilai perusahaan, yang memberikan pengaruh bahwa ketika pertumbuhan ekonomi menurun maka nilai perusahaan menjadi naik.

5. Hasil pengujian terdapat pengaruh positif dan signifikan kinerja keuangan terhadap nilai perusahaan, yang memberikan hubungan bahwa ketika kinerja keuangan mengalami peningkatan maka nilai perusahaan akan meningkat.

6. Hasil pengujian terdapat pengaruh negatif dan signifikan keputusan pendanaan terhadap nilai perusahaan, yang memberikan hubungan bahwa ketika keputusan pendanaan mengalami penurunan maka nilai perusahaan akan meningkat. 
7. Hasil pengujian terdapat pengaruh positif dan tidak signifikan keputusan investasi terhadap nilai perusahaan, ketika keputusan investasi mengalami peningkatanmaka nilai perusahaan akan meningkat.

8. Hasil uji koefisien determinasi menunjukkan $14 \%$ nilai perusahaandapat dijelaskan oleh variabel suku bunga, nilai tukar, pertumbuhan ekonomi, kinerja keuangan, keputusan pendanaan dan keputusan investasi sedangkan sisanya sebesar $86 \%$ dijelaskan oleh variabel yang lain yang tidak diteliti

\section{DAFTAR PUSTAKA}

Arif, M. (2010). Teori Makro ekonomi: Konsep, Teori dan Analisis. Bandung : Alfabeta

Bursa Efek Indonesia. (2015-2019).Laporan Keuangan. Indonesia.

Dendawijaya. (2003). Manajemen Perusahaan. Jakarta: Ghalia Indonesia.

Devi Ni Nyoman, S.J. (2019). Pengaruh ROE, DER, dan Nilai Tukar Terhadap Return Saham. Retrieved on 29th September 2020.

Firdaus, M. (2011). Pengantar Teori Moneter Serta Aplikasinya Pada Sistem Ekonomi.Bandung: Alfabeta.

Ghozali, Imam. 2013. Aplikasi AnalisisMultivariate dengan Program IBM SPSS 21Update PLS Regresi. Semarang: Badan Penerbit UniversitasDiponegoro.

Husnan, S. (2000). Manajemen Keuangan Teori dan Penerapan (keputusan Jangka Panjang). Edisi 4. Yogkarta: BPFE.

Idamiharti, I. (2017). Keputusan Keuangan, Kondisi Eksternal dan Nilai Perusahaan (Studi Empiris: Perusahaan Food and Beverage di Indonesia). Jurnal Poli Bisnis, 9(1).

Ismail. (2010). Manajemen Perusahaan (Teori Menuju Aplikasi). Jakarta: Kencana.

Iswandono. (1999). Suku Bunga Diturunkan Investasi Akan Meningkat. Jurnal Ekonomi dan Bisnis Indonesia. Vol 14, N0. 2, Hal 34-42.

Kuncoro, M. (2004). Otonomi \& Pembangunan Daerah: Reformasi, Perencanaan, Strategi dan peluang. Jakarta: Erlangga.

Maimunah, S., \& Hilal, S. (2018). Pengaruh Keputusan Investasi, Keputusan Pendanaan, Kebijakan Dividen Dan Tingkat Suku Bunga Terhadap Nilai Perusahaan. JIMFE (Jurnal Ilmiah Manajemen Fakultas Ekonomi), 6(2), 4249.

Mardi, Rina Walmiaty. (2008). Pengaruh Struktu Aktiva, profitabilitas dan Kebijakan Deviden Terhadap Struktur Pendanaan (Studi Empiris Pada Industri Perbankan). Tesis. Fakultas Ekonomi. Universitas Sumatera Utara.

Najmiyah, dkk. 2014. Pengaruh Price To Book Value (PBV), Price Earnings Ratio (PER) dan Debt To Equity Ratio (DER) Terhadap Return Saham Pada Industri Real Estate dan Property yang Terdaftar di Bursa Efek Indonesia Periode 2009-2013. Jurnal Akutansi, Vol. 2, No. 1.

Nelwan, A., \& Tulung, J. E. (2018). Pengaruh Kebijakan Dividen, Keputusan Pendanaan Dan Keputusan Investasi Terhadap Nilai Perusahaan Pada Saham Bluechip Yang Terdaftar Di BEI. Jurnal EMBA: Jurnal Riset Ekonomi, Manajemen, Bisnis dan Akuntansi, 6(4).

Noviyanti, V., Mardani, R. M., \& Wahono,B. (2019). Pengaruh keputusan investasi, keputusan pendanaan, dan tingkat suku bunga terhadap nilai perusahaan 
pada perusahaan manufaktur sub sektor makanan dan minuman tahun 20142017. Jurnal Ilmiah Riset Manajemen, 8(1).

Riyanto, B. (2011).Dasar-Dasar Pembelanjaan Perusahaan. BPFE: Yogyakarta.

Robert, A. (2001). Pasar Modal Indonesia (The Intelligent Guide to Indonesian Capital Market). Jakarta: Mediasoft Indonesia.

Sartono, A. (2001). Manajemen Keuangan Teori dan Aplikasi. Yogyakarta: BPFE. Subagyo, et al. (2018). Pengaruh PDB, Inflasi, Dan BI Rate Terhadap Nilai Perusahaan Periode 2010-2017. Jurnal Ekonomi Dan Bisnis Vol 3 No 2.

Sutrisno. (2003). Manajemen keuangan (Teori, Konsep dan Aplikssi), Edisi pertama. Yogyakarta : EKONISIA.

Tandelilin, E. (2010). Portofolio dan Investasi,.Yogyakarta: Penerbit ANDI

Todaro, M. P. \& Stephen C. S. (2011). Pembangunan Ekonomi Edisi Kesebelas Jilid 1. Jakarta: Erlangga.

Weston, J.F and T.E. Copeland. (1997). Manajemen keuangan Jilid kedua (Terjemahan A. Jaka Wasana dan Kirbandroko). Jakarta: Bina Rupa.

Wijaya,T.(2013).Metodologi Penelitian Ekonomi dan Bisnis: Teori dan Pratik. Yogyakarta: Graha Ilmu 